\title{
The Effect of Discipline and Work Environment on Employee Performance in Ciputat Sector Police
}

\author{
Rima Handayani \\ Universitas Pamulang \\ E-mail: dosen00551@ unpam.ac.id
}

(Received: December-2018; Reviewed: February-2019; Accepted: March-2019;

Avalaibel Online: March-2019; Published: March-2019)

(c) (5) (5) This is an open access article distributed under the Creative Commons Attribution License EY CC-BY-NC-4.0 (2019 by author (https://creativecommons.org/licenses/by-nc/4.0/)

\begin{abstract}
Human Resources (HR) is very important to be able to carry out the role of tasks, operationalize the available technology and provide innovative and creative thinking. The purpose of this study was to determine how the Effect of Discipline and Work Environment on Employee Performance in Ciputat Sector Police, where the independent variables studied were Discipline (X1) and Work Environment (X2), while the dependent variable was Employee Performance (Y). This method uses a quantitative approach, with the nature of descriptive associative research. The statistical tool used in the form of multiple linear regression, and carried out through the SPSS program 20 populations taken were Ciputat Sector Police officers as many as 108 people and the sample technique used was using the Slovin formula so that the number of respondents sampled was 52 people. In testing the hypothesis the author uses the $t$ test for partial hypotheses and the $\mathrm{f}$ test for simultaneous hypotheses. Based on partial hypothesis testing using the $f$ test and test where the test results show that the $f_{\text {count }}$ is 201.736> and $f$ table is 3.190 which means the independent variable $(\mathrm{X})$ has an influence on employee performance while the results of the $t$ test results in disciplinary variables produce $t$ arithmetic 4,613> and table 2,009 which means $t_{\text {count }}>t_{\text {table }}$ and work environment variables produce $t$ arithmetic of 6.353> and table of 2.009 which means $t_{\text {count }}>$ with a contribution value of $89.2 \%$ which means that the contribution of the Disciplinary variable ( X1) and Work Environment (X2) affect the variable Y (Employee Performance) that is equal to 89.2\% while the remaining $10.8 \%$ variable Y (Employee Performance) is influenced by other factors not examined by the author.
\end{abstract}

Keywords: Discipline; work environment; employee performance

\section{INTRODUCTION}

All companies are essentially founded with the aim of making a profit (Opka, 2008; Peter \& Olson, 2014; Sutisna, 2003; Swastha, Basu, 2014). To achieve the company's goals, the role of Human Resources (HR) is very important to be able to carry out the role of tasks, operationalize the available technology and provide innovative and creative thinking. Qualified 
and professional human resources are the main key in the growth and development of a company (Dessler, 2015; Hasibuan, 2011; Marwansyah, 2010; Siagian, 2015). Therefore, human resources need to be managed optimally so that the quantity and quality of human resources in the organization are truly in accordance with the needs and can be an organizational asset in winning the business competition.

Competition between companies in the era of globalization is increasingly sharp, so that human resources are required to continuously be able to develop themselves well (Sunarsi, 2018). Human resources must be human learners, namely individuals who want to learn and work hard with enthusiasm so that the potential for human beings is maximally developed (Rahadi, 2010; Sedarmayanti, 2017; Wirawan, 2015). Therefore, the human resources needed at this time are human resources who are able to quickly master technology against technological changes. In these conditions, personal integrity is increasingly important to win the competition (Agiskawati, Jamaluddin, Nasrullah, \& Salam, 2018; Ginanjar, Salam, \& Hermanto, 2017; M. S. Saggaf et al., 2018; S. Saggaf, Salam, Kahar, \& Akib, 2014).

Job stress is an important aspect for the company, especially its relation to employee performance (Musliha Fitri, 2013; Sari, Muis, \& Hamid, 2012; Wartono, 2017). Companies must have performance, good / high performance can help the company make a profit. Conversely, if the performance decreases can be detrimental to the company. Therefore employee performance needs to get attention, among others, by carrying out studies related to work stress variables. Stress can have the opposite effect, if the stress level experienced by nurses is low or within reasonable limits, then stress can be a motivation in the implementation of work so as to optimize performance (Mahardhika, 2017; Noviansyah, 1989; Yuswani, 2016).

In the short term, the stress that is left unattended without serious handling on the part of the company makes the employee become depressed, unmotivated, and frustrated causing the employee to work less than optimal so that his performance will be disrupted. In the long run, employees cannot withstand work stress so they are no longer able to work in the company. At an increasingly severe stage, stress can make employees become sick or even will resign (turnover). Through the mechanism of assessment of work performance will be known how well employees have performed the tasks given to him. Performance appraisal can also be used by the company to determine the shortcomings and potential of an employee. From these results the company can develop an overall human resource planning in facing the company's future. Employee performance is the results of the work functions / activities of a person or group in an organization that can be influenced by various factors to achieve organizational goals within a certain time period (Dika Arizona, 2013; Octarina \& Arischa, 2013; Ramadhani, 2016).

\section{METHOD}

The nature of this research is quantitative descriptive. The population in this study were employees of PT. Distribution of Sentra Jaya as many as 108 people. The number of samples taken in this study was determined by the Slovin formula according to Husen Umar (2001: 74) with an error rate of $10 \%$ in 52 respondents. Data collection methods using primary data and secondary data. Test the instrument using the validity and reliability test, the prerequisite data test uses the normality test, autocorrelation test, multicollinearity test, and heteroscedasticity test, while the statistical tests use multiple regression equations, correlation coefficient test, coefficient of determination test and significance test. 


\section{RESULT AND DISCUSSION}

This research was conducted at Ciputat Sector Police, which is located at Jln. Ir. Juanda No. 70 Pisangan Ciputat 15419, South Tangerang

\section{Classic Assumption Test}

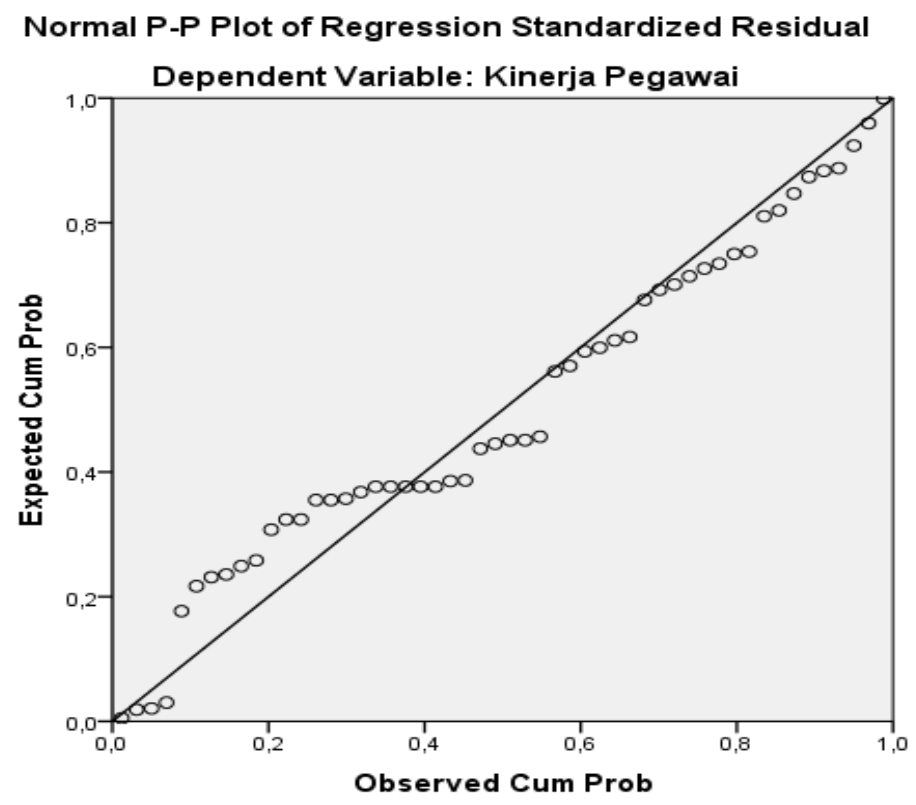

Figure 1.

Data Normality Test

From the figure 1 above it can be seen that the points spread around the line and follow the diagonal line, the residual value is normal.

Tabel 1.

Normalitty Test

One-Sample Kolmogorov-Smirnov Test

\begin{tabular}{llr}
\hline & & $\begin{array}{c}\text { Unstandardized } \\
\text { Residual }\end{array}$ \\
\hline $\mathrm{N}$ & Mean & 52 \\
Normal Parameters & a,b & Std. Deviation \\
& Absolute & 1,73211448 \\
& Positive &, 116 \\
Most Extreme Differences & Negative &, 102 \\
& &,- 116 \\
Kolmogorov-Smirnov Z & &, 837 \\
Asymp. Sig. (2-tailed) & &, 486 \\
\hline
\end{tabular}

a. Test distribution is Normal. 
b. Calculated from data.

From the above output, it can be seen that the significance value (Asymp. Sig 2-tailed) is 0.486. Because the significance is more than $0.05(0.486>0.05)$, the residual value is normal.

Table 2.

Multicollinity Test

Coefficients $^{\mathrm{a}}$

\begin{tabular}{|c|c|c|c|c|c|c|c|}
\hline \multirow[t]{2}{*}{ Model } & \multicolumn{2}{|c|}{$\begin{array}{l}\text { Unstandardized } \\
\text { Coefficients }\end{array}$} & \multirow{2}{*}{$\begin{array}{c}\begin{array}{c}\text { Standardized } \\
\text { Coefficients }\end{array} \\
\text { Beta }\end{array}$} & \multirow[t]{2}{*}{$\mathrm{T}$} & \multirow[t]{2}{*}{ Sig. } & \multicolumn{2}{|c|}{$\begin{array}{c}\text { Collinearity } \\
\text { Statistics }\end{array}$} \\
\hline & B & $\begin{array}{l}\text { Std. } \\
\text { Error }\end{array}$ & & & & Tolerance & VIF \\
\hline (Constant) & 1,813 & 2,192 & & ,827 & ,412 & & \\
\hline Discipline & ,435, & 094, & ,413 & 4,613 & ,000 & ,276 & 3,619 \\
\hline $\begin{array}{l}\text { Environment } \\
\text { Employee }\end{array}$ & ,540 & ,085 & ,568 & 6,353 & ,000 & ,276 & 3,619 \\
\hline
\end{tabular}

a. Dependent Variable: Employee Performance

Multicollinearity test was used to find out whether the regression model found a correlation between independent variables. A good regression model should not occur the correlation between independent variables. Multicollinearity can be known from the tolerance value and the value of the Variance Inflation Factor (VIF). From table 4.18, it can be seen that the tolerance value is more than 0.10 and the VIF value of all variables is below 10 so that it can be concluded that there is no multicollinearity among the independent variables.

The heteroscedasticity test aims to test whether in the regression model there is an inequality of variance from the residuals of one observation to another. If the residual variance of one observation to another observation is still called homokesdacity and if different is called heteroscedasticity

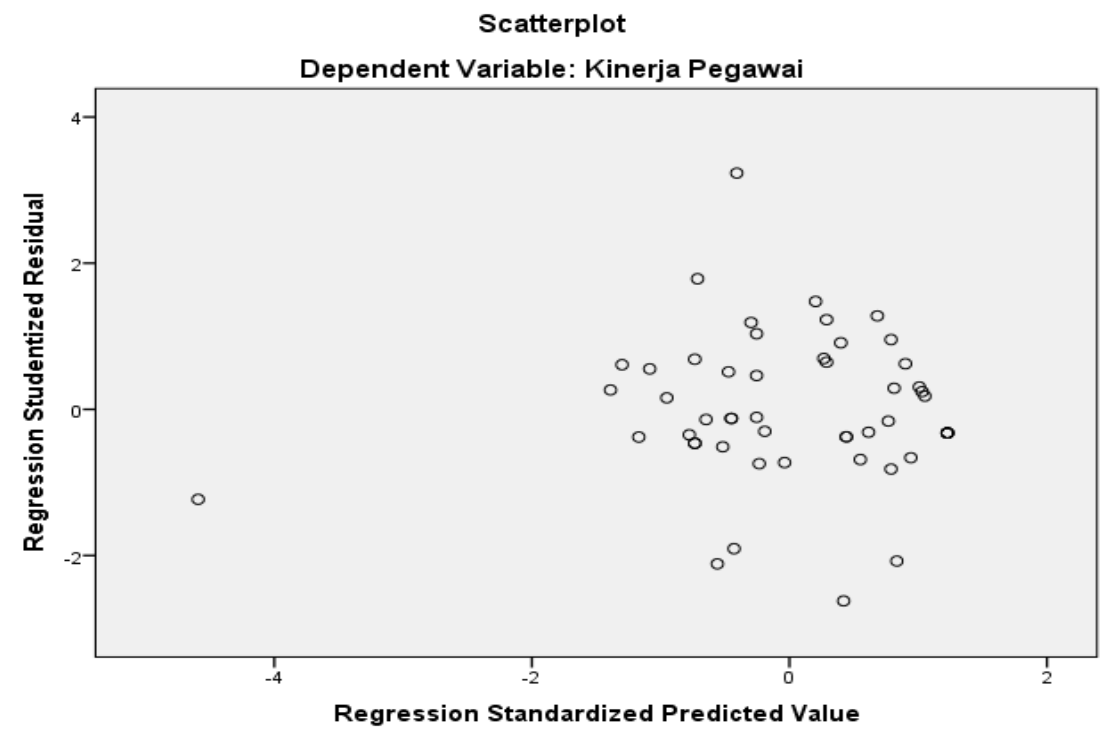

Figure 2.

\section{Heteroscedasticity Test}


The heteroscedasticity test aims to test whether in the regression model there is an inequality of variance from the residuals of one observation to another. If the residual variance of one observation to another observation is still called homokesdacity and if different is called heteroscedasticity.

The autocorrelation test in the study used the Durbin Watson test (DW test) and obtained the results as in the table as follows:

Table 3.

Autocorrelation

Model Summary ${ }^{b}$

\begin{tabular}{|c|c|c|c|c|c|}
\hline Model & $\mathrm{R}$ & R Square & $\begin{array}{l}\text { Adjusted R } \\
\text { Square }\end{array}$ & $\begin{array}{l}\text { Std. Error of the } \\
\text { Estimate }\end{array}$ & Durbin-Watson \\
\hline 1 &, $944^{\mathrm{a}}$ & 892 & 887 & 1,767 & 2,089 \\
\hline
\end{tabular}

a. Predictors: (Constant), Work Environment, Discipline

b. Dependent Variable: Employee Performance

In table 3. Obtained DW value of 2.089 we will compare the value of the table using a significant $5 \%$ of the number of samples $52(\mathrm{n})$ and the number of variables $3(\mathrm{k}-3)$, then the Durbin Watson table will get a DU value of 1.676 and DL value of 1.433 , therefore the value of DW $(2,089)>$ DU $(1,676)<4-D L(4-1,433=2,567)$ and included in the category du <d <4-dl, it can be concluded that there is no autocorrelation.

\section{Product Moment Correlation Coefficient Test Analysis}

Correlation test aims to determine the level of closeness of the relationship between variables expressed by the correlation coefficient (r).

Table 4.

Correlation Test

\section{Correlations}

\begin{tabular}{llrrr}
\hline & & Discipline & $\begin{array}{c}\text { Work } \\
\text { Environment }\end{array}$ & $\begin{array}{c}\text { Empoyee } \\
\text { Performance }\end{array}$ \\
\hline \multirow{2}{*}{ Discipline } & Pearson Correlation & 1 &, $851^{* *}$ &, $896^{* *}$ \\
& Sig. (2-tailed) & &, 000 &, 000 \\
& $\mathrm{~N}$ & 52 & 52 & 52 \\
\multirow{3}{*}{ Work Environment } & Pearson Correlation &, $851^{* * *}$ & 1 &, $919^{* *}$ \\
& Sig. (2-tailed) &, 000 & &, 000 \\
Employee & $\mathrm{N}$ & 52 & 52 & 52 \\
Performance & Pearson Correlation &, $896^{* * *}$ &, $919^{* * *}$ & 1 \\
& Sig. (2-tailed) &, 000 &, 000 & \\
\hline
\end{tabular}

**. Correlation is significant at the 0.01 level (2-tailed).

Table 4 for the disciplinary relationship significant value of $0,000<0.05$, while for the work environment relationship a significant value of $0,000<0.05$, it can be concluded that the Discipline variable (X1) and the Work Environment (X2) on Performance (Y) there is a positive correlation between Discipline and the Work Environment on performance. Pearson correlation for Discipline with a performance of 0.896 which is included in the very strong category. As for the Environment with a Performance of 0.919 which is included in the very strong category (0.80 to 100$)$. 


\section{Multiple Linear Regression Test}

Table 5

Multiple Linear Regression Test

Coefficients $^{\mathrm{a}}$

\begin{tabular}{|c|c|c|c|c|c|c|c|}
\hline \multirow[t]{2}{*}{ Model } & \multicolumn{2}{|c|}{$\begin{array}{l}\text { Unstandardized } \\
\text { Coefficients }\end{array}$} & \multirow{2}{*}{$\begin{array}{c}\text { Standardize } \\
d \\
\text { Coefficients }\end{array}$} & \multirow[t]{2}{*}{$\mathrm{t}$} & \multirow[t]{2}{*}{ Sig. } & \multicolumn{2}{|c|}{$\begin{array}{l}\text { Collinearity } \\
\text { Statistics }\end{array}$} \\
\hline & $B$ & $\begin{array}{l}\text { Std. } \\
\text { Error }\end{array}$ & & & & Tolerance & VIF \\
\hline (Constant) & 1,813 & 2,192 & & ,827 &, 412 & & \\
\hline 1 Discipline & ,435 & ,094 & ,413 & 4,613 & ,000 & 276 & 3,619 \\
\hline $\begin{array}{l}\text { Work } \\
\text { Environment }\end{array}$ & 540, & 085, & 568, & 6,353 & ,000 & 276, & 3,619 \\
\hline
\end{tabular}

a. Dependent Variable: Employee Performance

Based on table 5 of SPSS version 20 above, the regression equation can be formulated, namely: $\mathrm{Y}=1,813+0.435(\mathrm{X} 1)+0.540(\mathrm{X} 2)$. The constant value (a) of 1,813 means that even without the influence of the Discipline (X1) and Work Environment (X2) variables, employees still have a performance level of 1,813. Discipline Variable has a positive effect on performance with a coefficient value of 0.435 , meaning that each increase in Discipline (X1) is one-unit, then Performance (Y) will increase by 0.435 assuming Discipline (X1) is considered constant. The Work Environment variable has a positive effect on performance with a coefficient value of 0.540 , meaning that each increase in the Work Environment (X2) is one unit, the Performance (Y) will increase by 0.540 assuming the Work Environment (X2) is considered constant.

\section{Determination Coefficient Test}

The coefficient of determination is between zero or one. A small R2 value means that the ability of the independent variables to explain the variation of the dependent variable is very limited, and vice versa if a value close to 1 means that the independent variables provide almost all information needed to predict the dependent variables.

Table 6.

Disciplinary Variable Determination Coefficient Test (X1)

Model Summary ${ }^{\mathrm{b}}$

\begin{tabular}{|c|c|c|c|c|}
\hline Model & $\mathrm{R}$ & R Square & Adjusted R Square & Std. Error of the Estimate \\
\hline 1 &, $896^{\mathrm{a}}$ & 803 & ,799 & 2,362 \\
\hline
\end{tabular}

a. Predictors: (Constant), Discipline

b. Dependent Variable: Employee Performance

R Square Determination R Coefficient value of 0.803 . The data indicates that Discipline on Performance contributed $80.3 \%$. 
Table 7.

Test Coefficient of Determination of Work Environment Variables (X2) Model Summary ${ }^{\mathrm{b}}$

\begin{tabular}{llrrr}
\hline Model & R & R Square & Adjusted R Square & \multicolumn{2}{c}{$\begin{array}{c}\text { Std. Error of the } \\
\text { Estimate }\end{array}$} \\
\hline 1 &, $919^{\mathrm{a}}$ &, 845 &, 842 & 2,095 \\
\hline
\end{tabular}

a. Predictors: (Constant), Lingkungan Kerja

b. Dependent Variable: Kinerja Pegawai

$\mathrm{R}$ Square Determination R Coefficient value of 0.845 . The data indicates that the Work Environment on Performance contributed 84.5\%.

Table 8.

Determination Coefficient Test

\begin{tabular}{llrrrr}
\hline Model & $\mathrm{R}$ & $\mathrm{R}$ Square & Adjusted R Square & \multicolumn{2}{c}{$\begin{array}{c}\text { Std. Error of the } \\
\text { Estimate }\end{array}$} \\
\hline 1 &, $944^{\mathrm{a}}$ & &, 892 &, 887 & 1,767 \\
\hline
\end{tabular}

Based on the above outputs the following results can be obtained:

$\mathrm{R}$ coefficient value of 0.944 . This means that the correlation of $\mathrm{X} 1$ and $\mathrm{X} 2$ to $\mathrm{Y}$ is 0.944 between the Discipline and Work Environment variables on Performance. R Square Determination R Coefficient value of 0.892. The data indicates that Discipline and the Work Environment on Performance contributed $89.2 \%$. The remaining $10.8 \%$ is caused by other factors outside this study.

\section{Test of Significance}

Table 9

T-Test for the Effect of Discipline (X1) and Work Environment (X2) on Employee Performance (Y).

\begin{tabular}{|c|c|c|c|c|c|c|c|c|}
\hline \multirow[t]{2}{*}{ Model } & \multicolumn{2}{|c|}{$\begin{array}{l}\text { Unstandardized } \\
\text { Coefficients }\end{array}$} & \multirow{2}{*}{$\begin{array}{c}\begin{array}{c}\text { Standardized } \\
\text { Coefficients }\end{array} \\
\text { Beta }\end{array}$} & \multirow[t]{2}{*}{$\mathrm{t}$} & \multirow[t]{2}{*}{ Sig. } & \multicolumn{3}{|c|}{ Correlations } \\
\hline & B & $\begin{array}{l}\text { Std. } \\
\text { Error }\end{array}$ & & & & $\begin{array}{l}\text { Zero- } \\
\text { order }\end{array}$ & Partial & Part \\
\hline (Constant) & 1,813 & 2,192 & & ,827 &, 412 & & & \\
\hline${ }_{1}$ Disiplin & ,435 & ,094 & ,413 & 4,613 & ,000 & 896 &, 550 & ,217 \\
\hline $\begin{array}{l}\text { Work } \\
\text { Environment }\end{array}$ & ,540 & ,085 & ,568 & 6,353 & ,000 & 919 & ,672 & 299 \\
\hline
\end{tabular}

Based on the SPSS output above we can see that the t value of the Discipline variable (X1) is greater than the value of t table $(4,613<2,009)$ with a significant level below 0.05 which is 0,000 and $t_{\text {count }}$ the Work Environment variable (X2) is greater than $t_{\text {table }}$ value (6.353>2.009) with a significant level below $0.05,0.000$. Based on the t-test decision-making method in this analysis, the regression can be concluded that the Work Environment variable (X2) is more influential on Employee Performance (Y). 
Table 10

F Test The Effect of Discipline (X1) and Work Environment (X2) on Employee Performance (Y).

\begin{tabular}{|cc|c|c|c|c|c|}
\hline \multicolumn{1}{|c|}{ Model } & $\begin{array}{c}\text { Sum of } \\
\text { Squares }\end{array}$ & df & Mean Square & F & Sig. \\
\hline \multirow{4}{*}{1} & Regression & 1259,912 & 2 & 629,956 & 201,736 &, $000^{\mathrm{b}}$ \\
& $\begin{array}{c}\text { Residual } \\
\text { Total }\end{array}$ & 153,011 & 49 & 3,123 & & \\
\hline
\end{tabular}

a. Dependent Variable: Employee Performance

b. Predictors: (Constant), Work Environment, Discipline

From the results of statistical tests, it was found that $F_{\text {count }}>F_{\text {table }}$ is obtained that 201.736> 3.190 with a significant level of $0.000<0.05$ so it can be concluded that Ho was rejected with the understanding that "there is a significant influence between discipline (X1) and work environment (X2) simultaneously on employee performance (Y) at Ciputat Sector Police.

\section{CONCLUSION}

Based on the research detail the $\mathrm{R}$ Square Determination $\mathrm{R}$ coefficient value is 0.803 . The data indicate that the effect of Discipline on Performance is $80.3 \%$. R Square Determination $\mathrm{R}$ Coefficient value of 0.845 . The data indicate that the influence of the Work Environment on Performance by $84.5 \%$. Based on the correlation coefficient test between Discipline and the Work Environment on performance. R Square Determination R Coefficient value of 0.892. The data indicate that Discipline and the Work Environment on Performance contributed 89.2\%. The remaining $10.8 \%$ is caused by other factors outside this study. Based on the t-test, the t count value of the Discipline variable (X1) is greater than the table value $(4,613<2,009)$ with a significant level below 0.05 ie 0,000 and the t count of the Work Environment variable (X2) is greater than the $t$ table value $(6,353>2,009)$ with a significant level below 0.05 which is 0,000 . Based on the results of the $\mathrm{f}$ test, by comparing the $\mathrm{f}$ arithmetic and $\mathrm{f}$ tables, we obtain $\mathrm{f}$ arithmetic 201.736> $\mathrm{f}$ tables 3.19, and the significant value is 0.000 smaller than the significant level of 0.05 .

\section{REFERENCES}

Agiskawati, A., Jamaluddin, J., Nasrullah, M., \& Salam, R. (2018). Efektivitas Pemanfaatan Komputer pada Kantor Pengadilan Tata Usaha Negara Makassar. Jurnal Office, 4(1), 1318.

Dessler, G. (2015). Manajemen Sumber Daya Manusia. In Jakarta: Salemba Empat.

Dika Arizona, H. R. dan N. H. (2013). Analisis Pengaruh Gaya Kepemimpinan, Motivasi Kerja dan Komitmen Organisasional terhadap Kinerja Pegawai (Studi pada Dinas Kelautan dan Perikanan Kabupaten Malang). Api Student Journal.

Ginanjar, A., Salam, R., \& Hermanto, F. (2017). Penggunaan Facebook sebagai Media Pembelajaran IPS. JOINT INTERNATIONAL SEMINAR.

Hasibuan, M. S. P. (2011). Manajemen Sumber Daya Manusia. Edisi Revisi Jakarta: Bumi Aksara. 
Mahardhika, T. S. (2017). Hubungan Antara Masa Kerja Dengan Stres Kerja Pada Tenaga Kerja Bagian Winding di PT Iskandar Indah Printing Textile Surakarta. Jurnal Keperawatan.

Marwansyah. (2010). Manajemen Sumber Daya Manusia. Alfabeta: Jakarta. https://doi.org/10.1017/CBO9781107415324.004

Musliha Fitri, A. (2013). Analisis Faktor-faktor yang Berhubungan dengan Kejadian Stres Kerja pada Karyawan Bank (Studi pada Karyawan Bank Bmt). Jurnal Kesehatan Masyarakat Universitas Diponegoro.

Noviansyah, Z. \&. (1989). Pengaruh Stres Kerja Dan Motivasi Kerja Terhadap Kinerja Karyawan PT. Perkebunan Minanga Ogan Baturaja. Journal of Chemical Information and Modeling. https://doi.org/10.1017/CBO9781107415324.004

Octarina, A., \& Arischa. (2013). Pengaruh Etos Kerja Dan Disiplin Kerja Terhadap Kinerja Pegawai Pada Dinas Kebudayaan Pariwisata Pemuda Dan Olahraga Kabupaten Sarolangun. Manajemen S-1. https://doi.org/10.1017/CBO9781107415324.004

Opka, D. (2008). Pemasaran Jasa. Akademik. https://doi.org/10.1177/0300985809357753

Peter, J. P., \& Olson, J. C. (2014). Perilaku Konsumen dan Strategi Pemasaran. In salemba empat.

Rahadi, D. R. (2010). Manajemen Kinerja Sumber Daya Manusia. In Applied Physics A: Materials Science and Processing. https://doi.org/10.1007/s00339-002-1913-7

Ramadhani, S. D. (2016). Pengaruh Kepemimpinan Dan Motivasi Terhadap Kinerja Pegawai Di Balai Pengembangan Kegiatan Belajar (Bpkb) Daerah Istimewa Yogyakarta (Diy). In Jurnal Ilman.

Saggaf, M. S., Aras, M., Akib, H., Salam, R., Baharuddin, A., \& Kasmita, M. (2018). The Quality Analysis of Academic Services Based on Importance Performance Analysis (IPA).

Saggaf, S., Salam, R., Kahar, F., \& Akib, H. (2014). Pelayanan Fungsi Administrasi Perkantoran Modern. Jurnal Ad'ministrare, 1(1), 20-27.

Sari, R., Muis, M., \& Hamid, N. (2012). Pengaruh Kepemimpinan, Motivasi, Dan Stres Kerja Terhadap Kinerja Karyawan Pada Bank Syariah Mandiri Kantor Cabang Makassar. Jurnal Analisis.

Sedarmayanti. (2017). Manajemen Sumber Daya Manusia. In Manajemen Sumber Daya Manusia.

Siagian, S. P. (2015). Manajemen Sumber Daya Manusia. In Jakarta : Bumi Aksara.

Sunarsi, D. (2018). Seminar Perencanaan Sumber Daya Manusia. ISBN - 978.602.70082.1.7.

Sutisna. (2003). Perilaku Konsumen: Teori dan penerapannya dalam Pemasaran. Ghalia Indonesia, Jakarta. https://doi.org/10.1007/BF01013984

Swastha, Basu, I. (2014). Manajemen Pemasaran Modern. In Liberty, Yogyakarta. https://doi.org/10.1017/CBO9781107415324.004

Wartono, T. (2017). Pengaruh Stres Kerja Terhadap Kinerja Karyawan (Studi Pada Karyawan Majalah Mother and Baby). Jurnal Ilmiah Prodi Manajemen Universitas Pamulang.

Wirawan. (2015). Manajemen Sumber Daya Manusia Indonesia. In Depok.

Yuswani, W. (2016). Pengaruh Budaya Organisasi dan Stress Kerja dan Dampaknya Terhadap 


\section{Pinisi Discretion Review}

Volume 2, Issue 2, March, 2019 Page. 125- 134

Kinerja Karyawan Pada PT. Kerinci Permata Motor Jambi. Jurnal Sainstech Politeknik Indonusa Surakarta. 